\title{
Effect of Epstein-Barr virus infection on global gene expression in nasopharyngeal carcinoma
}

\author{
Yuan-Chii Gladys Lee • Yu-Chyi Hwang • \\ Kuang-Chi Chen • Yong-Shiang Lin • Dah-Yeou Huang • \\ Tao-Wei Huang • Cheng-Yan Kao • Han-Chung Wu • \\ Chin-Tarng Lin $\cdot$ Chi-Ying F. Huang
}

Received: 9 April 2006 /Revised: 14 June 2006 / Accepted: 18 June 2006 / Published online: 19 September 2006

(C) Springer-Verlag 2006

\begin{abstract}
It was proposed that Epstein-Barr virus (EBV) is closely associated with nasopharyngeal carcinoma (NPC); however, the molecular mechanisms involved in the effect of EBV on NPC host genes have not yet been well defined. For this study, two sets of microarray experiments, NPC (EBV-free) vs normal epithelial cells and $\mathrm{EBV}^{+}$vs $\mathrm{EBV}^{-}$ NPC arrays, were analyzed and the datasets were crosscompared to identify any correlation between gene clusters involved in EBV targeting and the NPC host gene
\end{abstract}

Accession numbers of the genes used in the study are GEO: GSE2370, GEO: GSE2371, and GEO: GPL1885.

Electronic supplementary material Supplementary material is available for this article at http://dx.doi.org/10.1007/s10142-0060035-2 and is accessible for authorized users.

Y.-C. G. Lee

Graduate Institute of Biomedical Informatics,

Taipei Medical University,

Taipei, Taiwan, Republic of China

Y.-C. G. Lee

Bioinformatics Computing Center, Taipei Medical University,

Taipei, Taiwan, Republic of China

\section{Y.-S. Lin}

National Institute of Cancer Research,

National Health Research Institutes,

Miaoli, Taiwan, Republic of China

K.-C. Chen

Department of Chemical Engineering,

National Chung Cheng University,

Chiayi, Taiwan, Republic of China

C.-T. Lin

Department of Pathology, National Taiwan University Hospital,

Taipei 100, Taiwan, Republic of China expression profiles. Statistical analysis revealed that EBV seems to have a preference for targeting more genes from the differentially expressed group in NPC cells than those from the ubiquitously expressed group. Furthermore, this trend is also reflected in log ratios where the EBV target genes of the differentially expressed group origin showed greater $\log$ ratios than genes with an origin from the ubiquitously expressed NPC group. Taken together, the genome-wide comparative scanning of EBV and NPC
Y.-C. Hwang • D.-Y. Huang $\cdot$ H.-C. Wu Institute of Pathology, College of Medicine,

National Taiwan University,

Taipei, Taiwan, Republic of China

C.-T. Lin $(\bowtie)$

Institute and Department of Pathology,

College of Medicine,

National Taiwan University,

Taipei 100, Taiwan, Republic of China

e-mail: ctl@ha.mc.ntu.edu.tw

H.-C. Wu

Institute of Oral Biology,

College of Medicine,

National Taiwan University,

Taipei, Taiwan, Republic of China

T.-W. Huang $\cdot$ C.-Y. Kao

Department of Computer Science and

Information Engineering,

National Taiwan University,

Taipei, Taiwan, Republic of China

\section{C.-Y. F. Huang}

National Institute of Cancer Research, National Health Research Institutes, Taipei 114, Taiwan, Republic of China 
transcriptomes has successfully demonstrated that EBV infection has an intensifying effect on the signals involved in NPC gene expression both in breadth (the majority of the genes) and in depth (greater log ratios).

Keywords Epstein-Barr virus (EBV) - Nasopharyngeal carcinoma (NPC) - Transcriptomes · Quantitative real-time reverse transcriptase polymerase chain reaction (Q-RT-PCR)

\section{Introduction}

Nasopharyngeal carcinoma (NPC) is a common malignancy among Chinese living in South China, Taiwan, and Singapore (Waterhouse et al. 1982). In Taiwan, for example, the annual incidence of NPC is 5.3 cases per 100,000 individuals in the total population. However, the etiological factors have not been fully identified. It is suspected that hereditary and environmental factors, such as consumption of salted fish and Chinese herbs, long-term exposure to sulfuric acid vapors, and especially Epstein-Barr virus (EBV) infection, are closely associated with NPC pathogenesis (Armstrong et al. 1983; Ho et al. 1999; Klein et al. 1974; Niedobitek et al. 1991; Raab-Traub et al. 1983).

Insights into the strength of this relationship have come from the study of NPC patients. NPC can be subdivided into two histopathological types according to the World Health Organization (WHO) 1991 classification system (type I). Type I NPC (keratinizing squamous cell carcinoma) occurs sporadically all over the world and type II NPC (IIa, differentiated nonkeratinizing carcinoma; IIb, undifferentiated carcinoma) is highly prevalent and endemic in Southeast Asia, particularly the southern provinces of China, the Mediterranean basin, North Africa, and Alaska. Type I NPC is usually not associated with EBV, while type II, especially type IIb, is highly associated with EBV (Klein et al. 1974; Teng et al. 1996; Zur Hausen et al. 1970) and this type of NPC expresses viral proteins such as EBNA1, LMP1, LMP2A, LMP2B, and BARF0 as latent proteins (Brooks et al. 1992; Busson et al. 1988; Fahraeus et al. 1988; Gilligan et al. 1991; Hitt et al. 1989; Young et al. 1988) and BARF1 (Sbih-Lammali et al. 1996a,b), DNase (Sbih-Lammali et al. 1996a,b), BZLF1 (Cochet et al. 1993), and EA-D (Luka et al. 1988) as early antigens. Research has found a complex link between EBV infection and NPC and this was supported by the observations that EBV infection/status is associated with faster growth, less differentiation, and more metastasis of NPC tumors, in comparison to noninfected cases (Tsai et al. 1996). Moreover, the IgA antibody titer against EBV-viral capsid antigen is usually elevated in NPC patients' serum, and the EBV DNA sequence in certain NPC specimens is a monoclonal episomal form (Hsiao et al. 2002; Lin et al. 1997). Even in an animal model, EBV infection may also promote tumor proliferation and increase tumor size (Teramoto et al. 2000; Wu et al. 2003). Nevertheless, it is commonly recognized that EBV cannot infect untransformed squamous metaplastic epithelia (Lin et al. 1994, 1997; Lo et al. 2004). However, EBV infection is occasionally observed in NPC high-grade (transformed cells) but not in low-grade dysplastic epithelia, implying that some specific genetic changes are involved that precedes EBV infection during NPC progression (Lo et al. 2004).

To provide the fundamental knowledge required to understand the effect of EBV on NPC progression, genome-scale gene expression profiling using a cDNA microarray was used to scrutinize the genes that change expression and examine why they are changed. First, EBVindependent NPC tumor gene expression profiles were established by comparing NPC (EBV $\left.{ }^{-} \mathrm{NPC}\right)$ and normal nasal mucosal epithelia (normal). We took advantage of the characteristic in vitro that certain NPC cells contain an EBV genome and may gradually lose this during passage (Lin et al. 1994, 2000). This was used to establish EBV-free NPC cell lines. Second, EBV target gene expression profiles were subsequently established by comparing the $\mathrm{EBV}^{+} \mathrm{NPC}$ and $\mathrm{EBV}^{-}$NPC RNA transcriptomes. We adopted a receptor-mediated endocytosis method to reinfect the $\mathrm{EBV}^{-}$NPC and to establish $\mathrm{EBV}^{+}$NPC with highinfection efficiency (90-95\%) while, at the same time, retaining the in vivo physiological conditions (Lin et al. 1997, 2000; Wu et al. 2003). Traditionally, EBV infection in NPC is accomplished using cell-to-cell contact by a modified recombinant lymphotropic EBV, which normally alters or disturbs EBV characteristics (Imai et al. 1998; Nishikawa et al. 1999; Teramoto et al. 2000). Alternatively, EBV infection is established indirectly by preliminary transfection of cells with an extracellular plasmid containing EBV receptor, increasing susceptibility to NPC (Chang et al. 1998). However, the receptor-mediated endocytosis method proved to be closest to in vivo physiology, and an in vivo SCID mouse xenograft model was also carried out to show that both $\mathrm{EBV}^{-} \mathrm{NPC}$ and $\mathrm{EBV}^{+} \mathrm{NPC}$ cells retain their specific characteristics.

Finally, the two sets of microarray profiles were crosscompared and then analyzed by chi-square statistics and by two-dimensional coordination analysis. Taking this evidence as a whole, we were able to demonstrate clearly, and for the first time, that EBV tends to target and modify the differentially expressed host genes (including up- and downregulated genes) in NPC cells, rather than the ubiquitously expressed genes. This general enhancer role played by EBV may explain how this agent can affect a host to produce diverse pathological changes in transformed epithelial cells ranging from oral hairy leukoplakia to NPC. 


\section{Experimental methods}

Cell lines and cell culture

Five representative NPC cell lines (TW01, TW03, TW04, TW06, and CGBM1) were used for the cDNA microarray analysis. NPC-TW01 was derived from a keratinizing squamous cell carcinoma (WHO type I) (Lin et al. 1990) and NPC-TW03 was derived from a so-called lymphoepitheliomatous undifferentiated carcinoma (WHO, type IIb) (Lin et al. 1993). NPC-TW04 and NPC-TW06 were derived from two distinct undifferentiated carcinomas (WHO type IIb). The NPC-CGBM1 line was derived from a bone marrow metastatic NPC tumor tissue (type IIb; provided by Dr. S. K. Liao of Chang-Gung University Hospital). With the exception of TW04, all lines contained EBV DNA in the established cell lines; however, all became $\mathrm{EBV}^{-}$after 30 passages (Lin et al. 1993). In this study, all cell lines had progressed through 100 passages and contained 83 to $95 \%$ IgA receptor (secretory component protein) (Lin et al. 1997). All NPC cell lines were cultured in Dulbecco's Modified Eagle's Medium (DMEM) containing 5\% fetal calf serum (FCS) and were maintained at $37^{\circ} \mathrm{C}$ in a $10 \% \mathrm{CO}_{2}$ incubator. For preparation of normal nasal mucosal epithelial cells, nasal polyps obtained from polypectomy were immersed in the culture medium (DMEM plus FCS) with ice chips. After extensive dissection and cutting, tissue fragments were transferred to a petri dish and cultured in serum-free DMEM containing growth factors, as was described previously for the establishment of NPC cell lines (Lin et al. 1990). The cells were able to grow for about 20 passages. After six passages, the culture medium was replaced by DMEM containing 15 to $20 \%$ FCS without the addition of growth factors. These nasal polyps (provided by Dr. C. M. Liu of National Taiwan University Hospital) were obtained from different patients and were designated normal nasal mucosal cells (NNM 9, NNM12, and NNM13).

\section{Preparation of EBV particles}

Procedures for isolation of the EBV particles and identification of viral DNA in the isolated solution were performed according to a previously published report (Lin et al. 1997) with some modifications. Briefly, B95-8 cells, obtained from the American Type Culture Collection, were treated with 12-O-tetradecanoylphorbol-13-acetate for 14 days. The cells and culture medium were centrifuged at $1,500 \times g$ for $30 \mathrm{~min}$. The supernatant was then collected, bacitracin was added to inhibit viral aggregation, and the mixture was filtered using a $0.4-\mu \mathrm{m}$ filter. After recentrifugation at $29,000 \times g$, the precipitate was dissolved in $1 \%$ of the original volume of RPMI-1640 medium. Part of the viral solution was subjected to PCR analysis for EBV DNA, as detailed in our previous paper (Lin et al. 1997).

EBV infection and verification of EBV in the infected NPC cells

The procedure for EBV infection of NPC cells was performed using receptor-mediated endocytosis as was described previously (Lin et al. 1997; Sixbey and Yao 1992) with some modification. After infection, the cells were collected and used for the following experiments. For the identification of EBNA-1 and EBV DNA in $\mathrm{EBV}^{+} \mathrm{NPC}$ cells, the NPC cells were cultured on coverslips for 10 days and then fixed for immunohistochemical localization using EBNA-1 monoclonal antibody (Calbiochem, USA) (Lin et al. 2000). In addition, in situ PCR hybridization was used to identify EBV DNA in the infected cells according to our previously published method (Lin et al. 1994). Normal mouse serum was used as an immunostaining control, and a nonspecific DNA probe as a negative control for the in situ PCR hybridization. Positive EBV protein and DNA signals were demonstrated in most of the infected NPC cells, similar to previously published data (Lin et al. 1997, 2000; $\mathrm{Wu}$ et al. 2003). The infected cells were counted in 15 highpower fields (HPF; 400×), showing an infection rate of more than $90 \%$.

In situ hybridization of EBER-1 in SCID mouse bearing EBV-infected xenograft tumor tissue

After EBV infection, $\mathrm{EBV}^{+}$and $\mathrm{EBV}^{-} \mathrm{NPC}$ cells were injected into various SCID mice $\left(1 \times 10^{7}\right.$ cells per mouse). Four weeks later, the xenograft tumor masses were removed, fixed in 3\% formaldehyde, embedded in paraffin block, and subjected to EBV-encoded small nuclear RNA-1 (EBER-1) in situ nucleic acid hybridization using the method as described previously (Wu et al. 2003).

Isolation of total RNAs from normal nasal epithelial cells, EBV-free, and EBV-containing NPC cells for cDNA microarray analysis

Total RNAs from each cell line were extracted using an RNeasy RNA extraction kit (Qiagen) together with DNase I treatment (Promega, USA). The total RNAs were reversetranscribed with Superscript II RNase H-reverse transcriptase (Gibco/BRL) to generate Cy3- and Cy5-labeled cDNA targets for control and experimental samples, respectively, according to the manufacturer's instructions. The labeled targets were hybridized on commercial 7500 cDNA microarrays representing approximately 7,500 distinct human transcripts (Egenomix Human UniversoChip 8K, Egenomix Technology, Taipei, Taiwan). Fluorescence intensities for 
Cy 3 and $\mathrm{Cy} 5$ targets were measured and scanned separately using a GenePix 4000B Array Scanner (Axon Instruments, Foster City, CA, USA).

\section{Microarray procedure}

Two microarray sets were constructed in this study (as summarized in Table 1). The first set consisted of NPC/ normal arrays, a direct comparison of EBV-free NPC cells and normal counterparts to distinguish gene expression patterns of NPC cells. It included five arrays for the five different NPC cell lines (TW01, TW03, TW04, TW06, and CGBM1, as described above), separately labeled with Cy5, and three mixed normal nasal mucosal epithelia (NNM9, NNM12, and NNM13, representing three normal individuals), which were labeled with $\mathrm{Cy} 3$. The second consisted of $\mathrm{EBV}^{+} / \mathrm{EBV}^{-}$arrays, an indirect comparison of $\mathrm{EBV}^{+}$ and $\mathrm{EBV}^{-}$NPC cells using a universal common reference RNA. It consisted of ten arrays representing five NPC cell lines with and without EBV infection with ten samples separately labeled with $\mathrm{Cy} 5$, while the common reference RNA was labeled with Cy3. The use of a common reference probe allowed us to treat these fluorescent ratios as measurements of the relative expression level of each gene across all experimental samples (Novoradovskaya et al. 2004; Ross et al. 2000). Common reference RNAs were used as a control channel for the $\mathrm{EBV}^{+} / \mathrm{EBV}^{-}$microarray, pooling total RNAs from equal quantities of the following 31 cell lines: HS-68, H1155, H522, HeLa, SiHa, MCF-7, H184B5F5/ M10, CCD-966SK, HepG2, Hep3B, CE81T/VGH, CE146T/VGH, T24, SW620, UB-09, HCT-116,
Gbm8401, Bcm1, Scm1, OECM-1, Jurkat, Normal fibroblast, Cx, 172, z183A, TSGH 8301, E7, CAL-27, IMR-32, 293, and Huh-7 (please refer to the web site for a detailed description found in supplementary Table S1). Each Cy5-labeled cDNA probe was combined with the Cy3labeled cDNA analog and the mixture hybridized to the microarray.

Data analysis

Data extraction was performed using GenePix Pro 3.0.5.56 (Axon Instruments). GeneSpring ${ }^{\mathrm{TM}} 5.0$ (SilicoGenetics, USA) was used for experimental normalization [per spot and per chip: intensity-dependent (Lowess) normalization], gene-list filtering [remove data with background (Cy3) of less than 10], statistical analysis, and gene-tree clustering (smooth correlation). An unsupervised hierarchical clustering algorithm was used to group genes with similar patterns of expression. The web interface, FatiGO (http://fatigo. bioinfo.cnio.es/), was used for further comparison of the distribution of gene ontology terms in the gene lists for EBV target and non-EBV target genes.

\section{Q-RT-PCR}

To confirm microarray data for the selected genes, the five original NPC cell lines, with and without EBV infection, were also used to validate their mRNA expression using quantitative real-time reverse transcriptase PCR (Q-RTPCR) approaches. Primer sequences (Table 2) designed using Primer Express software (Applied Biosystems, USA)

Table 1 Two sets of microarray designed in this study

\begin{tabular}{|c|c|c|c|}
\hline Name of array & Cy5 & Cy3 & GEO accession number \\
\hline \multicolumn{4}{|c|}{ NPC/normal arrays (GEO: GES2370) } \\
\hline TW01/normal & NPC-TW01 & Normal (mixture of NNM9, NNM12 and NNM13) & GSM44305 \\
\hline TW03/normal & NPC-TW03 & Normal (mixture of NNM9, NNM12 and NNM13) & GSM44306 \\
\hline TW04/normal & NPC-TW04 & Normal (mixture of NNM9, NNM12 and NNM13) & GSM44776 \\
\hline TW06/normal & NPC-TW06 & Normal (mixture of NNM9, NNM12 and NNM13) & GSM44307 \\
\hline CGBM1/normal & NPC-CGBM1 & Normal (mixture of NNM9, NNM12 and NNM13) & GSM44777 \\
\hline \multicolumn{4}{|c|}{$\mathrm{EBV}^{+} / \mathrm{EBV}^{-}$arrays $(\mathrm{GEO}: \mathrm{GES} 2371)$} \\
\hline Name of array & $\mathrm{Cy} 5$ & $\mathrm{Cy} 3$ & GEO accession \\
\hline TW01-EBV ${ }^{+}$ & NPC-TW01-EBV ${ }^{+}$ & Common reference RNA & GSM44783 \\
\hline TW03-EBV ${ }^{+}$ & NPC-TW03-EBV ${ }^{+}$ & Common reference RNA & GSM44784 \\
\hline TW04-EBV ${ }^{+}$ & NPC-TW04-EBV ${ }^{+}$ & Common reference RNA & GSM44785 \\
\hline TW06-EBV ${ }^{+}$ & NPC-TW06-EBV ${ }^{+}$ & Common reference RNA & GSM44786 \\
\hline CGBM1-EBV $^{+}$ & NPC-CGBM1-EBV ${ }^{+}$ & Common reference RNA & GSM44787 \\
\hline TW01-EBV ${ }^{-}$ & NPC-TW01 & Common reference RNA & GSM44778 \\
\hline TW03-EBV ${ }^{-}$ & NPC-TW03 & Common reference RNA & GSM44779 \\
\hline TW04-EBV ${ }^{-}$ & NPC-TW04 & Common reference RNA & GSM44780 \\
\hline TW06-EBV ${ }^{-}$ & NPC-TW06 & Common reference RNA & GSM44781 \\
\hline CGBM1-EBV $^{-}$ & NPC-CGBM1 & Common reference RNA & GSM44782 \\
\hline
\end{tabular}


Table 2 Primers used for the Q-RT-PCR validation

\begin{tabular}{|c|c|c|c|c|c|}
\hline Gene & Clone ID & Accession no. & Unigene & Forward $(\mathrm{F})$, reverse $(\mathrm{R})$ & Sequence \\
\hline \multirow[t]{2}{*}{$\mathrm{ADM}$} & \multirow[t]{2}{*}{774446} & \multirow[t]{2}{*}{ AA446120 } & \multirow[t]{2}{*}{ Hs.394 } & $\mathrm{F}$ & CGCCCACAAACTGATTTCTCA \\
\hline & & & & $\mathrm{R}$ & GTACAACACGCATTGCACTTTTC \\
\hline \multirow[t]{2}{*}{ Birc5 (survivin) } & \multirow[t]{2}{*}{796694} & \multirow[t]{2}{*}{ ВC034148 } & \multirow[t]{2}{*}{ Hs. 1578} & $\mathrm{~F}$ & TCAGCCCAACCTTCACATCTG \\
\hline & & & & $\mathrm{R}$ & CTGCTGCCTCCAAAGAAAGC \\
\hline \multirow[t]{2}{*}{ BST2 } & \multirow[t]{2}{*}{811024} & \multirow[t]{2}{*}{ AA485371 } & \multirow[t]{2}{*}{ Hs. 118110} & $\mathrm{~F}$ & GTGCTCCTGATCATCGTGATTC \\
\hline & & & & $\mathrm{R}$ & GACATTGCGACACTCCATCACT \\
\hline \multirow[t]{2}{*}{ BUB3 } & \multirow[t]{2}{*}{191904} & \multirow[t]{2}{*}{ H38804 } & \multirow[t]{2}{*}{ Hs. 40323} & $\mathrm{~F}$ & TCTGGACCTTAAATGGTAGAGGAAA \\
\hline & & & & $\mathrm{R}$ & TAGATTAACCTCCTCATGAAGCAGTCT \\
\hline \multirow[t]{2}{*}{ C20orf1 } & \multirow[t]{2}{*}{2469026} & AI950056 & Hs.9329 & $\mathrm{F}$ & TTGTTTCAAGGCTCGTCCAAA \\
\hline & & & & $\mathrm{R}$ & TTCCTGAACTAGAGAACCAGAAAGG \\
\hline CAPG & 841059 & AA486942 & Hs. 82422 & $\mathrm{~F}$ & ATGCCACTGGACAGATGAACCT \\
\hline & & & & $\mathrm{R}$ & TTTCGCCCCTTCCAGATATAGA \\
\hline CASP8 & 782488 & AA448468 & Hs. 381231 & $\mathrm{~F}$ & CAAGGATGCCTTGATGTTATTCC \\
\hline & & & & $\mathrm{R}$ & ATCTCСТCСТTTCTAGTGTTTAGGTAGGT \\
\hline $\mathrm{CD} 2 \mathrm{AP}$ & 595328 & AA173981 & Hs. 374340 & $\mathrm{~F}$ & TGGGACTGTTTCCCTCAAATTT \\
\hline & & & & $\mathrm{R}$ & TCCAGATGCAGTTTCACTCACAT \\
\hline CFLAR & 813714 & AA453850 & Hs. 195175 & $\mathrm{~F}$ & TCTCCAAGCAGCAATCCAAA \\
\hline & & & & $\mathrm{R}$ & AGCGCCAAGCTGTTCCTTAA \\
\hline DAD1 & 810039 & D15057.1 & Hs. 82890 & $\mathrm{~F}$ & GCAGTTATGTCGGCGTCGGTAG \\
\hline & & & & $\mathrm{R}$ & GTTCTGTGGGTTTGATCTGTATTC \\
\hline DUSP5 & 342378 & W65461 & Hs. 2128 & $\mathrm{~F}$ & GAAATCСТTСССТТССТСТАССТT \\
\hline & & & & $\mathrm{R}$ & GGGCTGTGATGTGCAAGTTG \\
\hline ERCC1 & 120468 & T95289 & Hs.59544 & $\mathrm{F}$ & TACCCCTCGACGAGGATGAG \\
\hline & & & & $\mathrm{R}$ & GCATATTCGGCGTAGGTCTGA \\
\hline HAS3 & 1933929 & AI338972 & Hs. 85962 & $\mathrm{~F}$ & TTTCCTTCATCTCCCACGAACT \\
\hline & & & & $\mathrm{R}$ & CTGATGTCAACCAGCAGTCTTACC \\
\hline HSPB2 & 324494 & W51795 & Hs.78846 & $\mathrm{F}$ & TCTCTCCCATGATGGCATCTTAA \\
\hline & & & & $\mathrm{R}$ & TGGCAATCAGGGCTCAACTAT \\
\hline IER3 & 810724 & AA480815 & Hs.76095 & $\mathrm{F}$ & GAGATGTTCCCCCTGCTGTAAA \\
\hline & & & & $\mathrm{R}$ & CСССАТТTСТTСТССТАСТTTGC \\
\hline IL1A & 1486083 & AA936768 & Hs. 1722 & $\mathrm{~F}$ & ATACCCAAAACCATCACAGGTAGTG \\
\hline & & & & $\mathrm{R}$ & AACAAGTTTGGATGGGCAACTG \\
\hline LMNA & 897544 & AA489582 & Hs. 77886 & $\mathrm{~F}$ & CGGGTGGATGCTGAGAACA \\
\hline & & & & $\mathrm{R}$ & TCATGACGGCGCTTGGT \\
\hline MAPKAPK3 & 342647 & ВC001662 & Hs. 227789 & $\mathrm{~F}$ & GTGGTGAGTTGTTCAGCAGGATT \\
\hline & & & & $\mathrm{R}$ & TCTCGGTGGGCAATGTTATG \\
\hline MAPKAPK5 & 448747 & AA778230 & Hs.30327 & $\mathrm{F}$ & GGATTTGCCAAGATTGACCAA \\
\hline & & & & $\mathrm{R}$ & CTCCTTCTGATGCCTTCTTTGC \\
\hline MT3 & 2019011 & AI362950 & Hs. 73133 & $\mathrm{~F}$ & AGCTGAGGCAGAAGCAGAGAA \\
\hline & & & & $\mathrm{R}$ & GAAAGGGAACACCAGGAACACT \\
\hline MYC & 812965 & AA464600 & Hs. 79070 & $\mathrm{~F}$ & GCTACGGAACTCTTGTGCGTAA \\
\hline & & & & $\mathrm{R}$ & CCAAGGTTGTGAGGTTGCATT \\
\hline NFKB1 & 789357 & M58603 & Hs. 83428 & $\mathrm{~F}$ & TTCTGGACCGCTTGGGTAACT \\
\hline & & & & $\mathrm{R}$ & TGGCTAGATGAATGGCATTCAG \\
\hline NRG2 & 1240116 & AA706226 & Hs. 113264 & $\mathrm{~F}$ & AGCCAAGTCCTATTGCGTCAAT \\
\hline & & & & $\mathrm{R}$ & TCTGGCATGTACAATCGCAAAG \\
\hline PTK2 & 855864 & AA630298 & Hs. 740 & $\mathrm{~F}$ & TGCAATATGCTAATCCCACTTTACA \\
\hline & & & & $\mathrm{R}$ & AGTTCCCGACCCAATGCTT \\
\hline RB1 & 487777 & M19701 & Hs. 75770 & $\mathrm{~F}$ & AATCCCTTGCATGGCTCTCA \\
\hline & & & & $\mathrm{R}$ & GAGGACAAGCAGATTCAAGGTGAT \\
\hline ROM1 & 223098 & H84113 & Hs. 281564 & $\mathrm{~F}$ & CCTCCCAAGGAGGATCTATCTGA \\
\hline & & & & $\mathrm{R}$ & CCAACCTGGAGCCTTGGTAAG \\
\hline SGK-F & 840776 & AA486082 & Hs. 296323 & $\mathrm{~F}$ & TGCATGCAAACACCCTGAAG \\
\hline & & & & $\mathrm{R}$ & TGATTTGCTGAGAAGGACTTGGT \\
\hline SNTA1 & 435330 & AA699926 & Hs.31121 & $\mathrm{F}$ & GGGTCAGCAGCAAGAGAAAGAA \\
\hline & & & & $\mathrm{R}$ & ATCCAAGAGTAAGGAGGAGAGAGACA \\
\hline
\end{tabular}


Table 2 (continued)

\begin{tabular}{llllll}
\hline Gene & Clone ID & Accession no. & Unigene & Forward (F), reverse $(\mathrm{R})$ & Sequence \\
\hline TARBP1 & 287745 & N62244 & Hs.151518 & $\mathrm{F}$ & GAAAACTGCTTTATGCCTGATTGG \\
& & & $\mathrm{R}$ & TTTCCGCTATACTGAGTCTTCATTCC \\
TCF20 & 2497775 & AI990386 & Hs.201668 & $\mathrm{F}$ & CCCAAGAACCTGAGATCAAACTAAA \\
& & & $\mathrm{R}$ & TACAAACGGCTCCAAGTTCACA \\
TCIRG1 & 2015083 & AI359884 & Hs.46465 & $\mathrm{F}$ & GAGTCTTCAACCACGTGCACTTT \\
& & & $\mathrm{R}$ & CCAGACACACAGCCACTTGTAGA \\
ZNF35 & \multirow{2}{*}{289923} & N64607 & Hs.288658 & $\mathrm{F}$ & GGTGCAGCTTTCATTTCCAACT \\
& & & $\mathrm{R}$ & TTATGACCAATGCTGGAGGTCTT \\
\hline
\end{tabular}

were used to perform Q-RT-PCR according to the manufacturer's instructions. Briefly, total RNAs from each cell line were extracted using the RNeasy RNA extraction kit (Qiagen) together with DNase I treatment (Promega) as mentioned above. Two micrograms of total RNAs from each cell line were subjected to reverse transcription using the ThermoScript RT-PCR system (Invitrogen, USA). The cDNA product (diluted $200 \times$ ) from each line was used to perform the Q-RT-PCR. Each $10 \mathrm{ml}$ of Q-RT-PCR reaction mixture contained $5 \mathrm{ml}$ of $2 \times$ SYBR Green Master Mixture, $0.5 \mathrm{ml}$ of $6 \mathrm{mM}$ PCR forward primers (final reaction concentration $300 \mathrm{nM}), 0.5 \mathrm{ml}$ of $6 \mathrm{mM}$ PCR reverse primer (final reaction concentration $300 \mathrm{nM}$ ), and $4 \mathrm{ml}$ of cDNA product mixture (diluted $200 \times$ ). The $\mathrm{Rn}$ value derived from the PCR amplification curve was used to calculate the relative mRNA copy number. We used glyceraldehyde dehydrogenase (GAPDH) mRNA as an internal control for comparison and to normalize the data. A melting point curve was used to identify the temperature where only the amplicon, and not the primer dimers, accounted for the SYBR green-bound fluorescence. Assays were performed in triplicate using an Applied Biosystems Model 7700 instruments. All of the primer sequences were designed by Primer Express software (Applied Biosystems). All of the primers were tested for nonspecific amplicons and primer dimers by visualizing PCR products on $2 \%$ agarose gels before performing the Q-RT-PCR. Only primers that did not generate nonspecific products and primer dimers were used for the Q-RT-PCR assay. The values from the Q-RT-PCR were normalized to the housekeeping gene GAPDH. We used the GAPDH gene as the internal control because the expression level of the gene was constant in the samples according to the microarray data (data not shown). A delta CT (threshold cycle) method was used. Briefly, the CT value of the internal control gene was used to calculate normalized target gene expression, referred to as delta CT, to correct differences between samples. Assays were performed in triplicate with an Applied Biosystems model 7700 instrument.

\section{Results}

SCID mouse bearing $\mathrm{EBV}^{+}$NPC forms undifferentiated carcinoma

We used five previously established EBV-free NPC cell lines (TW01, TW03, TW04, TW06, and CGBM1), employing receptor-mediated endocytosis to infect these cell lines with EBV: the EBV-infected NPC cell lines were designated as TW01-EBV ${ }^{+}$, TW03-EBV ${ }^{+}$, TW04-EBV ${ }^{+}$, TW06$\mathrm{EBV}^{+}$, and CGBM1-EBV ${ }^{+}$(Lin et al. 1997, 2000; Wu et al. 2003). Detailed characteristics and description of these NPC cell lines were reported previously (Lin et al. 1990, 1993), and they are described briefly in the "Experimental methods" section. To evaluate infection efficacy 10 days after EBV exposure, each EBV-infected cell line was fixed for EBNA-1 immunostaining and EBER-1 in situ PCR hybridization. Positive EBNA-1 immunoreactivity was demonstrated for over 90\% of the NPC cells (Fig. 1a-c). In addition, EBV-free NPC-TW06 was used as a negative control for EBV infection (Fig. 1d). The EBER-1 in situ hybridization data were similar to a recent report (Wu et al. 2004) and are not shown here.

To further examine whether the $\mathrm{EBV}^{-}$and $\mathrm{EBV}^{+} \mathrm{NPC}$ cells retained their in vivo characteristics, and to confirm that $\mathrm{EBV}^{+}$ NPC-transplanted SCID mouse cells still contained the EBV genome, we injected $\mathrm{EBV}^{+}$or $\mathrm{EBV}^{-} \mathrm{NPC}$ cells $\left(1 \times 10^{7}\right.$ cells per mouse injection) into ten SCID mice. SCID mouse samples injected with NPC-TW01 $1^{+}$are found in Fig. 1a-c,e and with $\mathrm{NPC}^{-T W 01}{ }^{-}$in Fig. 1b,d,f. After 4 weeks, the $\mathrm{EBV}^{+}$xenograft tumor mass (Fig. 2a,c) and the $\mathrm{EBV}^{-}$analog were approximately 2.3 and $1.8 \mathrm{~cm}$ in diameter, respectively (Fig. 2b,d). When paraffin sections from the xenograft tumor tissue were examined by hematoxylin and eosin staining, a picture of undifferentiated carcinoma was seen. If the sections were subjected to in situ hybridization for EBER-1, the EBER-1 signal was detected in most tumor cells in the EBV xenograft tissue (Fig. 2e); however, no EBV signal was discovered in the $\mathrm{EBV}^{-}$xenograft section (Fig. 2f). 
Fig. 1 Immunolocalization of EBNA-1 in EBV-infected NPC cells. a EBV-infected NPC-TW01 (TW01-EBV ${ }^{+}$). b EBV-infected NPC-TW03 $\left(\mathrm{TW} 03-\mathrm{EBV}^{+}\right)$. c EBV-infected NPC-TW06 (TW06-EBV ${ }^{+}$). d EBV-free NPC-TW06 (TW06$\mathrm{EBV}^{-}$); this was used as a negative control for EBV infection. a-d Staining with monoclonal antibody raised against EBNA-1. a-c The nuclei in culture cells from three cell lines (TW01, TW03, and TW06) all reveal clear anti-EBNA-1 immunoreactivity (as shown with arrows), but the staining intensity is somewhat cell-line-dependent. The average number of stained cells in HPF $(400 \times)$ is about $90 \%$ in each case. $\mathbf{d}$ The negative control shows no immunoreactivity subpanel $\mathbf{c}$ shows EBV signal in most tumor nuclei (arrows) from EBER-1 in in situ hybridization. $\mathbf{f}$ The section from subpanel d shows no EBV signal. (e: $200 \times$, f $100 \times$ )

Fig. 2 Identification of EBV signal in in vivo SCID mouse bearing $\mathrm{EBV}^{+}$xenograft tumor after infection, were injected subcutaneously into the flank of SCID mice. After 4 weeks, the tumor masses measured.

a, c The gross morphology of NPC cells and its xenograft tumor mass. b, d: The gross morphology of the SCID mouse bearing $\mathrm{EBV}^{-}$NPC cells and its xenograft tumor mass. The tumor mass in subpanel $\mathbf{c}$ is larger than that in subpanel d. e The paraffin tumor section from a TW01-EBV ${ }^{+}$

c TW06-EBV ${ }^{+}$
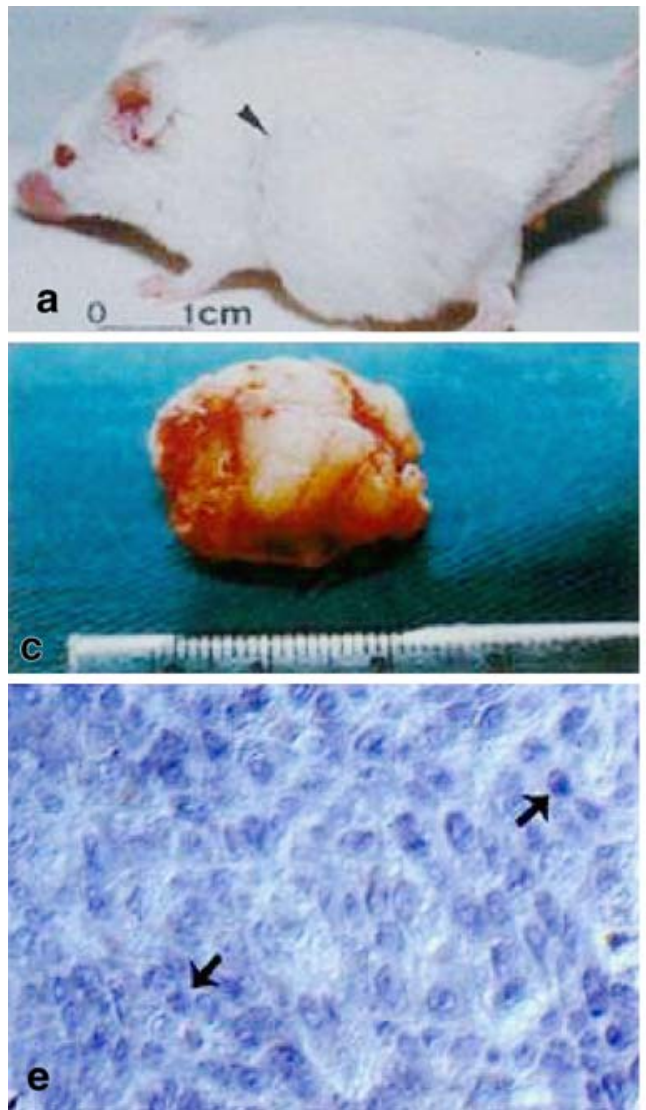
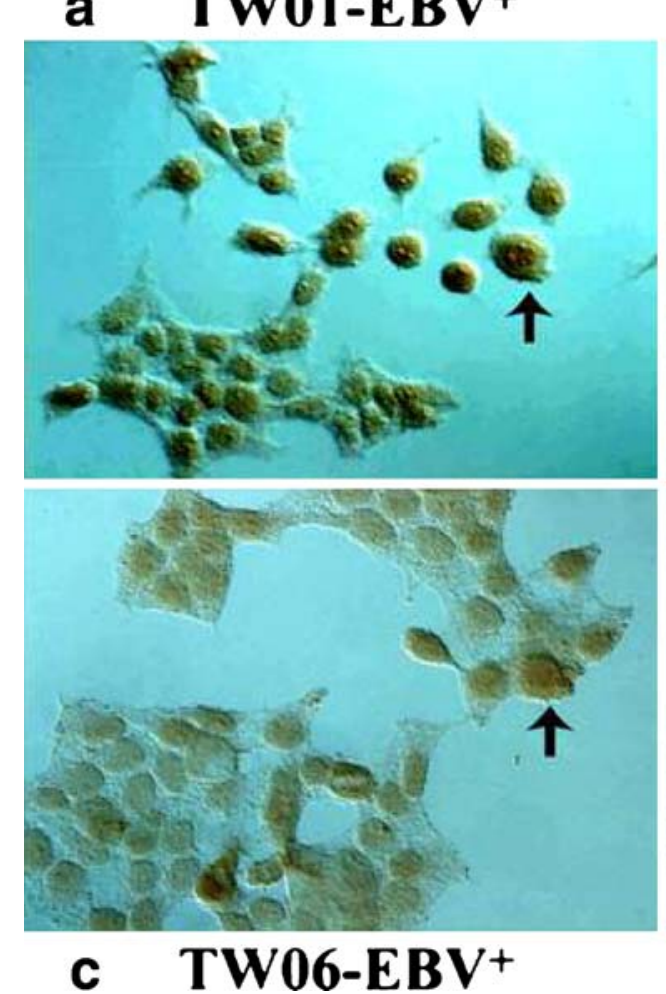

b TW03-EBV ${ }^{+}$
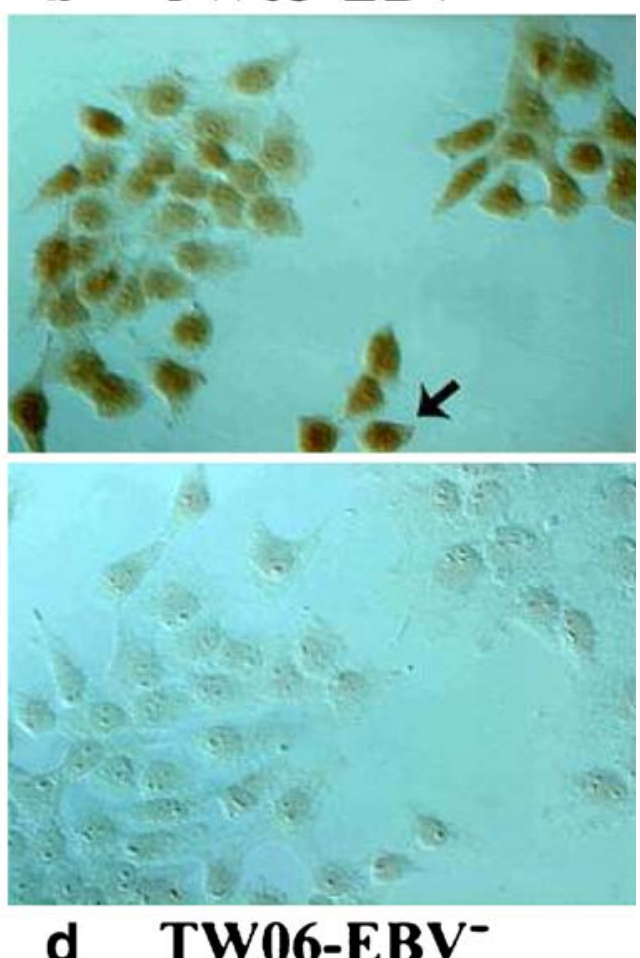

d TW06-EBV
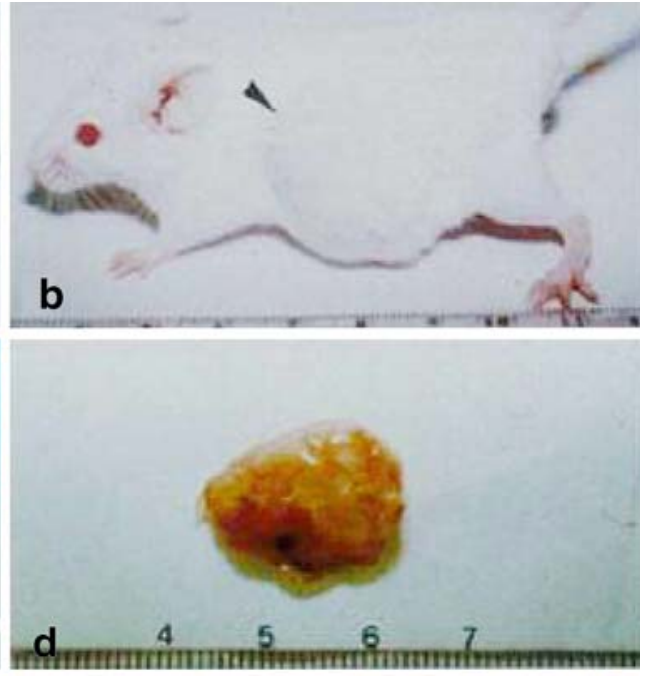

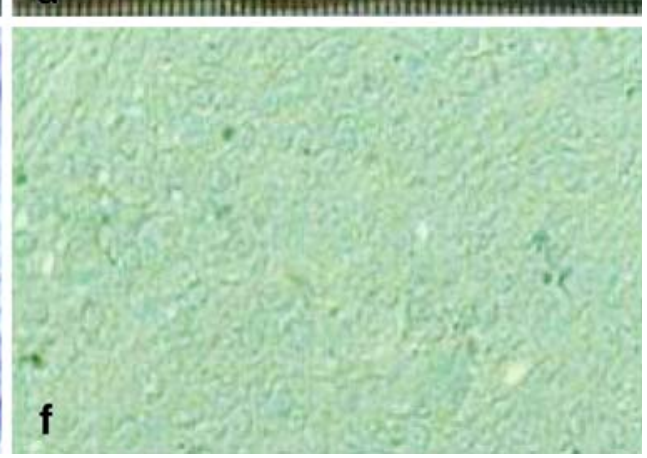


Analysis of gene expression in NPC/normal epithelial cells: criteria for gene classification and characteristics for gene groups

The first microarray set of NPC/normal was designed to compare gene expression for each of the five NPC cell lines from five individual patients to normal nasal mucosal epithelial cells. As a first step toward organizing results for visual display and further analysis, we used a hierarchical clustering algorithm to group the genes and the samples on the basis of similarity of expression pattern (data not shown). The keratinizing squamous carcinoma variant, TW01, was on a branch distinct from the undifferentiated analogs, TW03 and TW04, which were clustered together, while TW06 and CGBM1 formed a subgroup defined by distance from the other three of five NPC samples. Observed patterns of gene expression reflected genotypic differences between these NPC cell lines. Comparison of gene expression for NPC and its normal counterpart may be classified into several distinct categories, such as the differentially, ubiquitously, and ambiguously expressed groups, for which statistical results are presented in Table 3 and supplementary Fig. S1A. In brief, this statistical comparison of a total of 4,022 genes revealed that 1,054 were differentially expressed at the threshold of $\log _{2}$ ratio \pm 0.4 , including a total of 524 genes greater than 0.4 defined as an upregulated group (with a gene expression $\log _{2}$ ratio of $0.82 \pm 0.28$ ) and 530 less than -0.4 defined as a downregulated group (with a gene expression $\log _{2}$ ratio of $-1.16 \pm 0.78$ ) in all five of the NPC cell line varieties vs their normal counterpart. In addition, 825 genes with an expression intensity between \pm 0.4 were classified as a ubiquitously expressed group in NPC and normal nasal-mucosa epithelial cells (with a gene expression $\log _{2}$ ratio $0.01 \pm 0.14$ ). Some gene expression levels were not consistent in all five NPC lines (for example, those with a high coefficient of variance) and some did not qualify for the threshold set above; these were all classified as the ambiguously expressed group and excluded from further analysis. A boxplot demonstrated that the genes in all three groups, upregulated, downregulated, and ubiquitously expressed, displayed distinct expression levels (supplementary Fig.
S1A). The dataset is assigned as GSE2370 (individual samples are GSM44305, 44306, 44776, 44307, and 44777 representing NPC-TW01, TW03, TW04, TW06, and CGBM1, respectively) in Gene Expression Omnibus (GEO), National Center for Biotechnology Information (NCBI), with a GPL1885.

Analysis of gene expression in the $\mathrm{EBV}^{+} / \mathrm{EBV}^{-}$arrays: criteria for gene classification and characteristics for gene groups

Examining gene expression across a panel of five paired NPCs in the presence or absence of EBV allowed us to identify ubiquitously expressed genes, such as housekeeping and tumor-independent genes, and differentially expressed variants, which we have termed EBV target genes. We hypothesize that there is transmission of specific cellular and physiological functions from EBV to a cluster of EBV target genes. Detailed criteria for classification of differential, ubiquitous, and ambiguous expression are described in Table 4. Analysis of the set of $\mathrm{EBV}^{+} / \mathrm{EBV}^{-}$arrays reveals that of the total of 3,647 genes considered to have statistically significant results, which are present in four out of five paired arrays, 538 were differentially expressed at the threshold of $\log _{2}$ ratio \pm 0.2 . In the EBV-containing NPC cells, 294 with gene expression levels greater than 0.2 were defined as upregulated (with a gene expression $\log _{2}$ ratio of $0.42 \pm 0.16$ ) and 244 with less than -0.2 were defined as downregulated (with a gene expression $\log _{2}$ ratio of $-0.47 \pm 0.23$ ). In addition, 412 genes where the expression intensity was \pm 0.2 were considered ubiquitously expressed (with a gene expression $\log _{2}$ ratio of $0.01 \pm 0.6$ ), indicating their expression levels were independent of EBV infection and are described as non-EBV target genes. Gene expression levels that were not consistent in the five samples, such as those with a high coefficient of variance and those that could not be classified into the groups mentioned above, were all defined as members of the ambiguously expressed group and excluded from further analysis. A boxplot demonstrated that the genes in all three groups, upregulated, downregulated, and ubiquitously expressed,

Table 3 The selection criteria and definition of terms used in NPC/normal arrays

NPC/normal microarrays

Number of genes present in NPC/ normal

Total genes scores

Differentially expressed genes

Ubiquitously expressed genes

Ambiguously expressed genes
A given gene was scored in this analysis if a "present" call had been returned in all five expression profiles.

Genes $>0.4 \log$ ratio for all five arrays were defined as upregulated. Genes $<-0.4 \log$ ratio for all five arrays were defined as downregulated.

Genes between 0.4 and $-0.4 \log$ ratio in all five arrays were defined as ubiquitously expressed.

The rest of the genes were defined as ambiguously expressed.

4,022

524

530

825

2,143

Approximately $53.28 \%(2,143 / 4,022)$ genes with inconsistent expression across five arrays were excluded. A boxplot was used to demonstrate that the genes in the rest of three groups displayed distinct expression levels (supplementary Fig. S1A). 
Table 4 The selection criteria and definition of terms used in $\mathrm{EBV}^{+} / \mathrm{EBV}^{-}$arrays

\begin{tabular}{|c|c|c|c|}
\hline \multicolumn{2}{|l|}{$\mathrm{EBV}^{+} / \mathrm{EBV}^{-}$microarrays } & \multicolumn{2}{|c|}{$\begin{array}{l}\text { Number of genes present in } \\
\mathrm{EBV}^{+} / \mathrm{EBV}^{-}\end{array}$} \\
\hline Total genes scored & $\begin{array}{l}\text { A given gene was scored in this analysis if a "present" } \\
\text { call had been returned in four out of five paired arrays } \\
\text { (i.e., TW01-EBV }{ }^{+} \text {and TW01-EBV }{ }^{-} \text {are a pair). }\end{array}$ & & \\
\hline EBV target genes & Genes $>0.2 \log$ ratio were defined as upregulated. & 294 & 538 \\
\hline (i.e., differentially expressed genes) & Genes $<-0.2$ were defined as downregulated. & 244 & \\
\hline $\begin{array}{l}\text { Non-EBV target genes } \\
\text { (i.e., ubiquitously expressed genes) }\end{array}$ & $\begin{array}{l}\text { Genes between } 0.2 \text { and }-0.2 \\
\text { log ratio were defined as ubiquitously expressed. }\end{array}$ & & \\
\hline Ambiguously expressed genes & The rest of the genes were defined as ambiguously expressed. & & \\
\hline
\end{tabular}

Approximately $73.95 \%(2,697 / 3,647)$ genes with inconsistent expression across five arrays were excluded. A boxplot was used to demonstrate that the genes in the rest of three groups displayed distinct expression levels (supplementary Fig. S1B).

displayed distinct expression levels (supplementary Fig. S1B). The dataset is assigned as GSE2371 (individual samples are GSM44778, 44779, 44780, 44781, 44782, 44783, 44784, 44785, 44786, and 44787 representing NPC-TW01-EBV ${ }^{-}$,

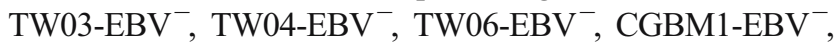
NPC-TW01-EBV ${ }^{+}$, TW03-EBV ${ }^{+}$, TW04-EBV ${ }^{+}$, TW06-

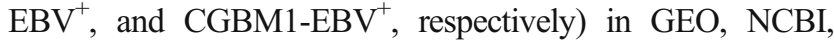
with a GPL1885.

Expression distribution in differentially and ubiquitously expressed genes between NPC/normal and $\mathrm{EBV}^{+} / \mathrm{EBV}^{-}$ arrays in quantitative and qualitative aspects

The proportion of genes in NPC cells sensitive to EBV infection was examined by studying the genes' expression levels that had changed in the presence of EBV and why those genes in particular were altered. $\mathrm{EBV}^{+} / \mathrm{EBV}^{-}$arrays were analyzed to distinguish genes that changed and, in NPC/normal arrays, to identify the original profiling before EBV came into play. Next, we cross-compared the two sets of microarrays mentioned above to trace the expression of every single gene from one array set to another. A detailed description is presented in Table 5. In brief, of the 294 differentially upregulated genes in the $\mathrm{EBV}^{+} / \mathrm{EBV}^{-}$arrays, 31 were also upregulated in the NPC/normal arrays with 31 downregulated and 30 unchanged (the rest of the genes were either ambiguous or absent as presented in Table 5). Of the 244 genes in the downregulated group in the $\mathrm{EBV}^{+}$/ $\mathrm{EBV}^{-}$arrays, 14 were upregulated in the NPC/normal arrays with 22 downregulated and 36 unchanged. As for the ubiquitously expressed group $(n=412)$ in the $\mathrm{EBV}^{+} / \mathrm{EBV}^{-}$ arrays, 23 were upregulated in the NPC/normal arrays with

Table 5 Expression distribution of genes between two microarray datasets

\begin{tabular}{|c|c|c|c|c|}
\hline $\mathrm{EBV}^{+} / \mathrm{EBV}^{-}$arrays & & NPC/normal arrays & & Ratio $^{a}$ \\
\hline \multirow[t]{2}{*}{ EBV target genes } & Up (294) & $\begin{array}{l}31 \text { upregulated } \\
31 \text { downregulated } \\
30 \text { ubiquitously expressed } \\
101 \text { ambiguously expressed } \\
101 \text { not present }\end{array}$ & $\begin{array}{l}21.1 \% \\
10.2 \%\end{array}$ & $\begin{array}{l}\text { Differentially expressed }(n=31+31+14+22=98) \text { : } \\
60 \% \text {; ubiquitously expressed }(n=30+36=66) \text { : } \\
40 \% \text { binomial test }<0.015\end{array}$ \\
\hline & Down (244) & $\begin{array}{l}14 \text { upregulated } \\
22 \text { downregulated } \\
36 \text { ubiquitously expressed } \\
97 \text { ambiguously expressed } \\
75 \text { not present }\end{array}$ & $\begin{array}{l}14.8 \% \\
14.8 \%\end{array}$ & \\
\hline Non-EBV target genes & $\begin{array}{l}\text { Ubiquitously } \\
\text { expressed (412) }\end{array}$ & $\begin{array}{l}23 \text { upregulated } \\
29 \text { downregulated } \\
84 \text { ubiquitously expressed } \\
132 \text { ambiguously expressed } \\
144 \text { not present }\end{array}$ & $\begin{array}{l}12.6 \% \\
20.4 \%\end{array}$ & $\begin{array}{l}\text { Differentially expressed }(n=23+29=52) \text { : } \\
38 \% \text { : ubiquitously expressed }(n=84) \text { : } \\
62 \% \text { binomial test }=0.008\end{array}$ \\
\hline
\end{tabular}

Expression distribution of genes in NPC/normal arrays from groups of genes, differentially expressed and ubiquitously expressed genes, in $\mathrm{EBV}^{+} / \mathrm{EBV}^{-}$arrays

${ }^{a}$ Only differentially expressed (including up- and downregulated) and ubiquitously expressed genes in $\mathrm{EBV}^{+} / \mathrm{EBV}^{-}$and $\mathrm{NPC}_{\text {normal arrays are }}$ considered. 
29 downregulated and 84 unchanged. To simplify the comparison, only the differentially and ubiquitously expressed genes were taken into account. Of 164 differentially expressed genes (i.e., EBV target genes) in the $\mathrm{EBV}^{+} /$ $\mathrm{EBV}^{-}$arrays (supplementary Fig. S2A, upper), 98 (60\%) were classified as differentially expressed genes and 66 $(40 \%)$ as ubiquitously expressed genes in the NPC/normal arrays (supplementary Fig. S2B, upper). In contrast, out of 136 ubiquitously expressed genes (i.e., non-EBV target genes) in the $\mathrm{EBV}^{+} / \mathrm{EBV}^{-}$arrays (supplementary Fig. S2A, lower), $52(38 \%)$ were classified as differentially expressed genes and $84(62 \%)$ as ubiquitously expressed genes in the NPC/normal arrays (supplementary Fig. S2B, lower). The gene number and $\log$ ratio are also illustrated using coordination with $Y$-axis representing NPC/normal arrays and $X$-axis representing the $\mathrm{EBV}^{+} / \mathrm{EBV}^{-}$arrays, as shown in Fig. 3a. The difference between Fig. 3a and supplementary Fig. S2 is the way they present gene expression levels; in the former case, they are displayed in color and the latter case by scale. Quantitatively speaking, a trend was demonstrated whereby a higher percentage of the EBV target genes in $\mathrm{EBV}^{+} / \mathrm{EBV}^{-}$arrays showed differential expression in NPC/normal arrays (60 vs $40 \%$, binomial test $<0.015$ ), and the non-EBV target genes in $\mathrm{EBV}^{+} / \mathrm{EBV}^{-}$ arrays tended to be ubiquitously expressed in NPC/normal
Table 6 Chi-square test results

\begin{tabular}{llll}
\hline Statistic & $d f$ & Value & $P$ value \\
\hline Chi-square & 1 & 13.773 & 0.0002 \\
Likelihood ratio chi-square & 1 & 13.885 & 0.0002 \\
Continuity adj. chi-square & 1 & 12.926 & 0.0003 \\
Mantel-Haenszel chi-square & 1 & 12.883 & 0.0003
\end{tabular}

Mantel-Haenszel common odds ratio estimate $=2.399$, $\mathrm{CI}$ of $\mathrm{OR}=$ $[1.505,3.822]$

arrays (62 vs $38 \%$, binomial test 0.008 ). More importantly, the trend was statistically significant $(p \leq 0.0003$, MantelHaenszel chi-square test; see Table 6). It demonstrates a directional bias than can be observed through the EBV targeting of the genome of NPC host. This bias suggests that EBV plays an enhancer role that augments NPC gene expression signals and strengthens the characteristics of NPC cells, rather than reforming the complete profile of the NPC transcriptomes.

Qualitatively, we also observed that EBV target genes from the differentially expressed group of NPC/normal arrays $(N=98$, mean $=0.4579 \pm 0.2382)$ had a more divergent $\log$ ratio change than those from the ubiquitously expressed group $(N=66$, mean $=0.3994 \pm 0.1380)$ as shown in Fig. 3b. Using an independent samples $t$ test, the two a

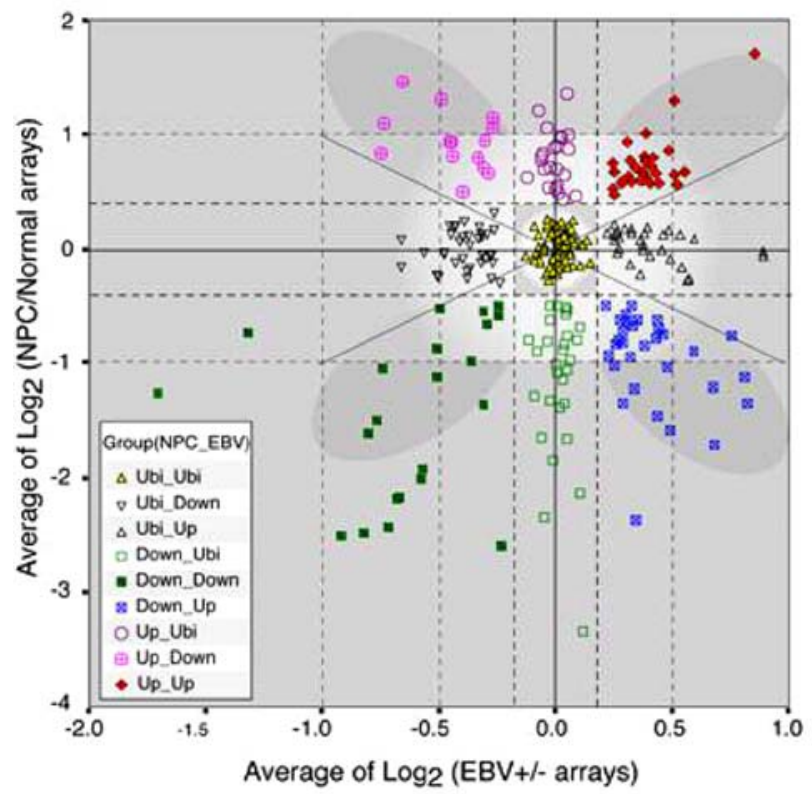

Fig. 3 Scatter plots of log ratio of gene expression levels between $\mathrm{EBV}^{+} / \mathrm{EBV}^{-}$arrays $(X$-axis) and NPC/normal (Y-axis). In subpanel a, the expression ratio of genes is illustrated in a two-dimensional coordination space with $\mathrm{EBV}^{+} / \mathrm{EBV}^{-}$array data as $X$-axis and $\mathrm{NPC} /$ normal array data as $Y$-axis. The genes can be divided into nine groups as indicated by the different marks. After combining the up- and downregulated genes into one differentially expressed group, the nine groups can then be reduced into four groups as indicated by subpanel

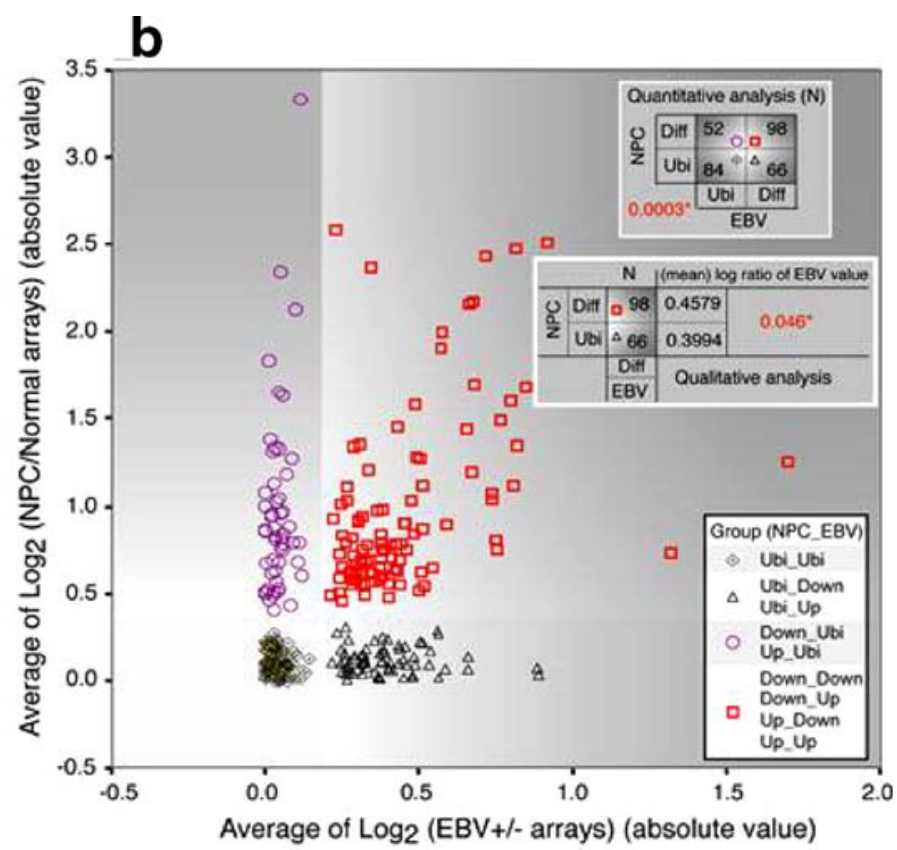

b. In the quantitative analysis, a chi-squared test was applied and the 0.0003 level of significance indicates a putative association between NPC and EBV. In the qualitative analysis, mean comparison between "NPC differentially expressed group that originated from EBV target genes" vs "ubiquitously expressed group that originated from EBV target genes" was conducted by an independent $t$ test, and a 0.046 level of statistical significance was obtained 
groups showed statistically significant differences between mean sample results ( $p=0.046$; Fig. $3 b)$. The scatter plot shown in Fig. $3 \mathrm{~b}$ was actually achieved by combining upand downregulated groups into one differentially expressed group from the homogenous scatter plot as shown in Fig. 3a. This statistical result further strengthens our hypothesis that EBV plays an enhancer role and this is based on a general economical biology viewpoint approach; that is, that a biological agent does not spend more than it needs to produce any necessary alterations. The logic behind comparing the $\mathrm{EBV}^{+} / \mathrm{EBV}^{-}$arrays results to the NPC/normal arrays as opposed to starting with virus infection and then moving to cancerous status is to calculate the conditional probability. We would like to address if these two events are connected. When two events, $A$ (genes differentially expressed in NPC) and $B$ (EBV target genes), are dependent, the probability of both occurring is: $p(A$ and $B)=p(A) \cdot p(B \mid A)$. It gives $p(B \mid A)=$ $p(A$ and $B) / p(A)$. Now, as shown in Table 7 , there are $32.7 \%$ (98) genes differentially expressed in both events, and there is a total $50 \%$ (150) genes differentially expressed in NPC. We would like to ask what percent of those genes that differentially expressed in NPC are also being differentially expressed upon EBV infection. And it gives $0.327 / 0.5=0.654=65.4 \%$. This argues that the results are simply a product of strong selection for the differentially expressed genes rather than the ubiquitously expressed genes on the NPC/normal arrays, which shows that EBV has modified the host (cancer) to thrive because it is the most effective and economical way for the virus to flourish itself.

The reason for grouping the data was to make a continuous dataset into a discrete dataset to allow data deduction. Using this method, the significance of the data is made clearer. Different ways of grouping would arguably change the number in each group and result in different specific statistical test values. However, the overall significance is unlikely to change. In the scatter plot of Fig. 3a, the trend is not changed because the diagonal genes in the $X$-axis $\left(\mathrm{EBV}^{+} / \mathrm{EBV}^{-}\right.$arrays) show greater $\log$ ratio than in the $Y$-axis (NPC/normal), meaning that EBV targeting genes in $\mathrm{EBV}^{+} / \mathrm{EBV}^{-}$arrays showed differential expression in NPC/normal array.

\section{Verification of selected genes using Q-RT-PCR}

The microarray analysis of the aberrant gene expression needs to be verified experimentally. We monitored the gene expression of 25 genes using Q-RT-PCR to compare expression in NPC/normal arrays, and of 16 genes to compare expression in $\mathrm{EBV}^{+} / \mathrm{EBV}^{-}$arrays. These genes were randomly selected from those shown in Fig. 3a that includes differentially or ubiquitously expressed genes, EBV target or nontarget genes. Analysis for each gene expression from microarray data and Q-RT-PCR analysis were compared with approximately 75 to $80 \%$ similarity demonstrated (Fig. 4). Inconsistent expression profiles were observed for approximately 20 to $25 \%$ of the analyzed genes, possibly the result of assay sensitivity and/or the quality of the individual samples. The way we calculated the error rate of microarray data with Q-RT-PCR is based on each gene in each individual tissue sample. However, in the microarray data analysis, each gene expression is calculated from the average of five different samples (NPC/normal or $\mathrm{EBV}^{+} / \mathrm{EBV}^{-}$tissues). In this regard, the error data from only one single sample would be reduced to become insignificant when the average data are used from five replicate samples.

Overall, the results of the Q-RT-PCR analysis of the 41 genes largely demonstrated a significant association with the cDNA microarray data, further validating the reliability and reproducibility of our methodology as a tool for identifying differentially expressed genes.

Using the stringent selection criteria derived from the 7.5-K gene chip, we are able to demonstrate empirically, from the quantitative viewpoint, that EBV tends to alter

Table 7 Quantitative distribution of gene clusters

\begin{tabular}{|c|c|c|c|c|c|c|}
\hline & & \multicolumn{4}{|c|}{$\mathrm{EBV}^{+} / \mathrm{EBV}^{-}$arrays } & \multirow{3}{*}{$\begin{array}{l}\text { Total frequency } \\
(\%)\end{array}$} \\
\hline & & \multicolumn{2}{|c|}{ EBV target genes } & \multicolumn{2}{|c|}{ Nontarget genes } & \\
\hline & & $\begin{array}{l}\text { Frequency } \\
(\%)\end{array}$ & $\begin{array}{l}\text { Column } \\
\text { percent }\end{array}$ & $\begin{array}{l}\text { Frequency } \\
(\%)\end{array}$ & $\begin{array}{l}\text { Column } \\
\text { percent }\end{array}$ & \\
\hline \multirow[t]{2}{*}{$\begin{array}{l}\text { NPC/normal } \\
\text { arrays }\end{array}$} & $\begin{array}{l}\text { Differentially expressed } \\
\text { genes }\end{array}$ & $98(32.7)$ & 60 & $52(17.3)$ & 38 & $150(50)$ \\
\hline & $\begin{array}{l}\text { Ubiquitously expressed } \\
\text { genes }\end{array}$ & $66(22.0)$ & 40 & $84(28.0)$ & 62 & $150(50)$ \\
\hline \multicolumn{2}{|c|}{ Total frequency $(\%)$} & \multicolumn{2}{|l|}{$164(54.7 \%)$} & \multicolumn{2}{|l|}{$136(45.3)$} & $300(100)$ \\
\hline
\end{tabular}

Quantitative distribution of gene clusters to determine the association of EBV target genes and non-EBV target genes with their different sources (differentially and ubiquitously expressed groups) from NPC/normal arrays, respectively. 
Fig. 4 Comparison of gene expression data from microarray analysis and Q-RT-PCR. The Q-RT-PCR values derived from PCR amplification (as described in "Experimental methods") represent 41 genes, normalized for GAPDH expression level and expressed in normal nasal mucosal cells, and NPC-EBV ${ }^{-}$ and NPC-EBV ${ }^{+}$cells, as indicated. Good correlation was demonstrated comparing gene expression results for the microarray data and the Q-RTPCR analysis
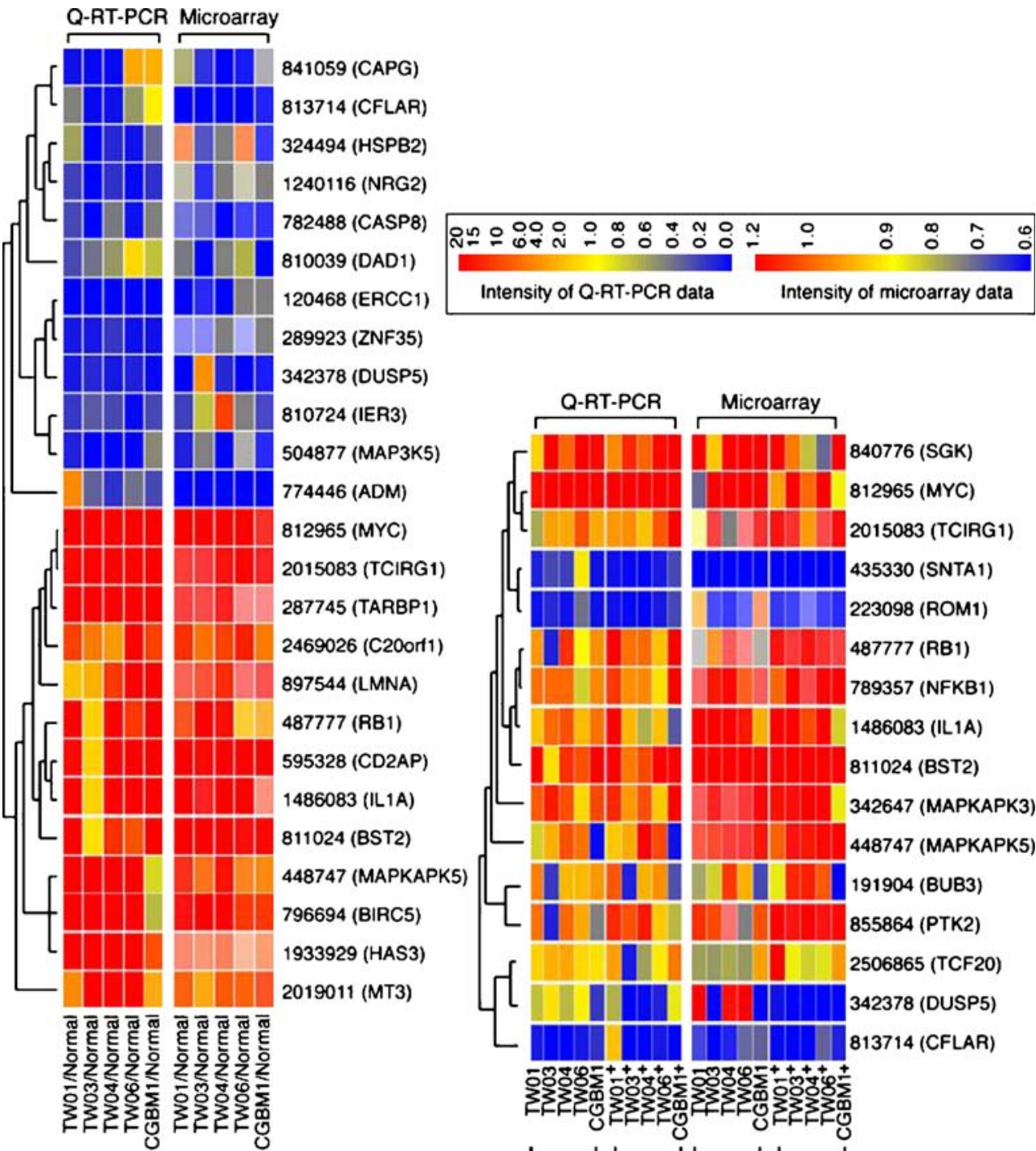

a

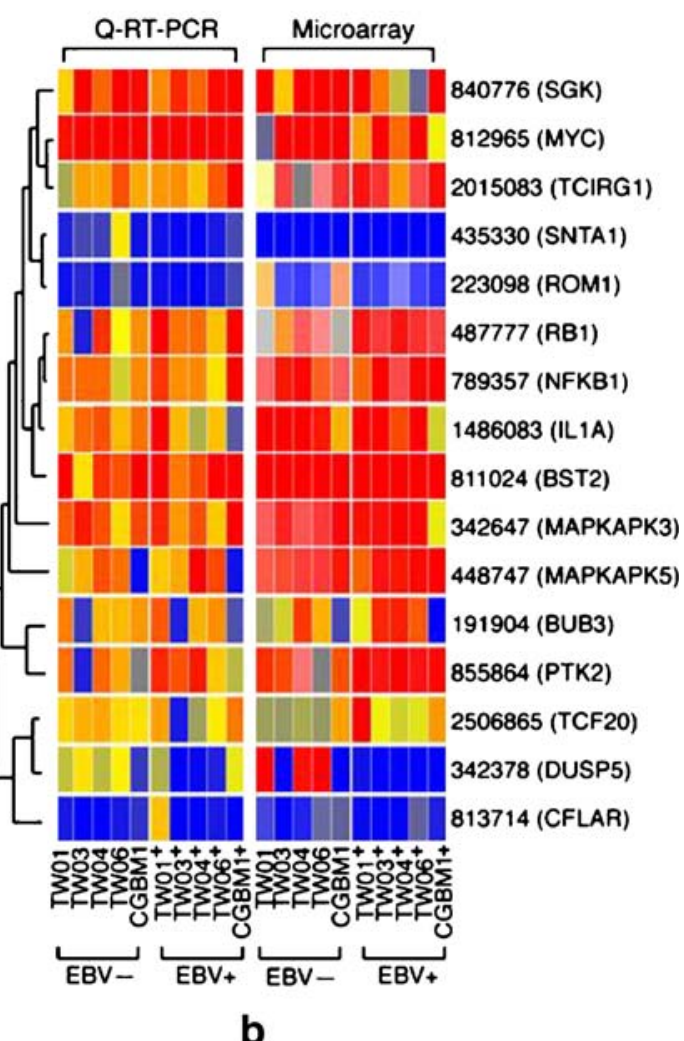

b more genes that are differentially expressed in EBV-free NPC cells than genes from ubiquitously expressed group. Vice versa, the non-EBV target genes have more genes from the ubiquitously expressed group than from the differentially expressed group when genome-wide transcriptomic screening is applied $(p \leq 0.0003)$. In qualitative terms, we find that EBV target genes from the differentially expressed group in NPC cells show greater log ratios than those from the ubiquitously expressed group $(p \leq 0.046)$. The microarray results were further verified using Q-RTPCR to show their reliability and reproducibility. This finding seems to suggest for the first time that the role of $\mathrm{EBV}$ is preferentially to modify the transcriptomic profiling of NPC at the molecular genotypic level and this is reflected in more malignant phenotypes, rather than changing the original transcriptomic structure, as depicted in Fig. 5. This plausible hypothesis also explains why a common factor such as EBV is able to be associated with such a wide range of diseases.

\section{Discussion}

Despite the fact that the majority of human adults worldwide are latently infected by EBV, only a very small percentage of them develop an EBV-associated malignancy such as NPC. Notwithstanding, there is general and longstanding agreement with respect to the strength of the relationship between EBV and NPC (Epstein 1978; Feng et al. 1999; Gunven et al. 1970; Henle and Henle 1970; Lin et al. 2001; Lo et al. 1999; Vasef et al. 1997). Although numerous studies have linked EBV infection to NPC, direct 
linkage has yet to be determined in terms of identification of the specific NPC gene expression changes in response to EBV infection, and the extent of the pathogenetic involvement of this infection in NPC host cells. Actually, EBV is not restricted to association with NPC. Latent EBV infection is controversially associated with numerous other illnesses, such as Burkitt's lymphoma (Ohigashi et al. 1985), Hodgkin's disease (Mueller et al. 1989), rheumatoid arthritis (Depper et al. 1981; Winrow et al. 1988), Sjogren's syndrome (Miyasaka et al. 1989), Kawasaki's disease (Kikuta et al. 1988), and chronic fatigue syndrome (Jones et al. 1985; Straus et al. 1988); association with other cancers is also shown, such as some gastric cancers (Lo et al. 2001), salivary gland cancer (Leung et al. 1995), and thymic carcinoma (Leyvraz et al. 1985). In this study, IgAreceptor-mediated endocytosis was utilized to achieve EBV infection of the NPC cells and to examine the effect of this infection and its interaction with NPC host gene expression, using both quantitative and qualitative analysis for comparison of two sets of microarrays. Our results show that the role of EBV is to intensify the level of expression of the NPC gene signals and this would seem to explain why a common agent such as EBV is able to be associated with such a wide range of diseases.

Fig. 5 Hypothetical model for the effect of EBV on NPC cells in the light of statistical evidence using genome-wide microarray screening. EBV causes host gene alteration only under a situation where a normal squamous epithelial cell was transformed (such as NPC in this case) and there is expression of the IgA receptor because normal squamous epithelial cells have no receptor for EBV infection. The gene expression regulation by EBV enhances the NPC gene expression profile by modifying the already differentially expressed genes and keeping the ubiquitously expressed genes untouched. The small red boxes (left lower corner) indicate the differentially expressed genes (including upand downregulated genes) and where the statistically significant majority were affected and amplified as denoted in bigger red boxes (right lower corner). It is worth noting that the reversible event of EBV infection was frequently observed in vitro, but has seldom been seen in vivo
When comparing gene expression between EBV-free NPC cells and normal nasal mucosal epithelia, it is interesting to note that a number of genes were being regulated in the NPC cells. In the five types of EBV-free NPC cell lines, there were 50 genes (1 upregulated, 49 downregulated) where expression was over 3 -fold higher than that of the normal analogs, 143 (20 up, 123 down) over 2-fold, and 402 (141 up, 261 down) over 1.5-fold higher. However, in a comparison of gene expression between EBVfree and EBV-infected NPC cells, there were relatively few NPC host genes being regulated by EBV. Only nine genes (2 upregulated: IMPA1 and ASE-1; and seven downregulated: EGR1, KRT19, RHOB, DUSP1, CYR61, DDIT3, and KRT14) had over 1.5-fold host gene expression differences in four out of the five NPC cell lines infected by EBV. This suggests that EBV may only modify the gene expression of NPC, rather than changing the cell major characteristics.

If we define the differentially expressed genes in the set of $\mathrm{EBV}^{+} / \mathrm{EBV}^{-}$arrays by a 1.05 -fold change in gene expression and analyze their gene ontology assignments, we can identify a subset of EBV target genes involved in critical cellular activities, such as proliferation, cell-cycle progression, and cell motility. Our results indicate that EBV-regulated genes may promote tumor progression and invasion. This is also in line with previous findings about

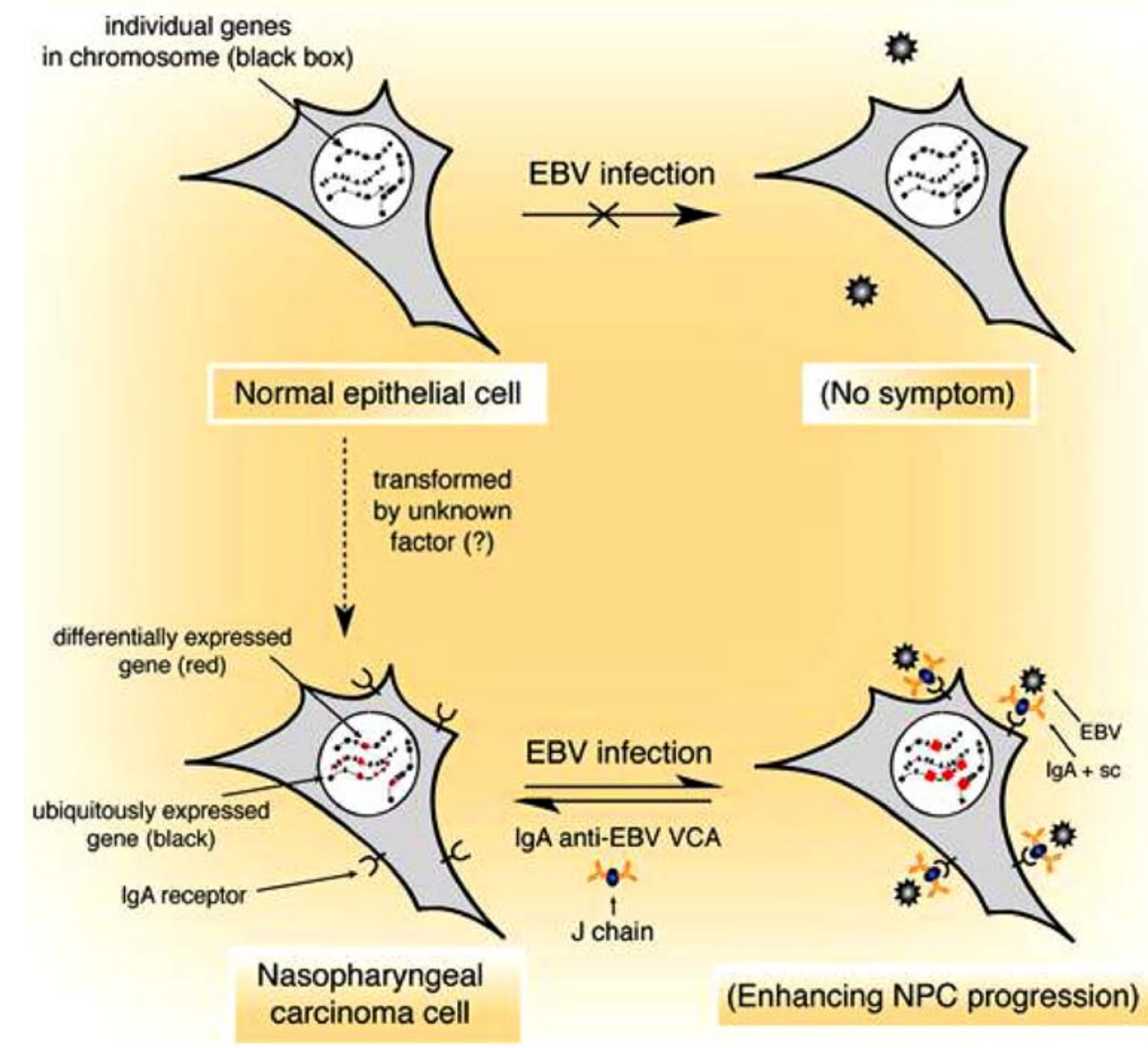


EBV enhancing NPC tumorigenicity and invasion (Teramoto et al. 2000; Wu et al. 2003). According to our microarray data, the genes involved in tumorigenicity include $T$ cell immune regulator 1 , insulin-like growth factor-binding protein 7 , bone marrow stromal-cell antigen 2 , insulin-induced gene 1, midkine (neurite growth-promoting factor 2), v-myc, protein kinase $C$, and $T G F-\beta 1$; and the genes involved in invasion (cell motility in gene ontology terms) include syntenin (syndecan-binding protein), syntrophin $\alpha-1$ (dystrophin-associated protein A1), myosin regulatory light-chain, and actin-related protein. We also found that caspase 3 and death-associated protein kinase-related 1 (also known as STK17A) were both downregulated on EBV infection. These findings suggest that EBV may not only promote NPC cell proliferation, but that it may also protect NPC cells from apoptosis.

Acknowledgements The authors wish to thank Dr. S. K. Liao of Chang-Gung University for providing the NPC-CGBM1 cell lines and Dr. C. M. Liu of National Taiwan University Hospital for the surgical specimens of nasal polyps. They would also like to thank Dr. ShihLan Hsu, Dr. Fen-Hwa Wong, Dr. Hsiao-Sheng Liu, Dr. Jenn-Han Chen, Dr. Cheng-Yang Chou, Dr. Li-Wha Wu, Dr. A-Min Huang, Dr. Wey-Jinq Lin, Dr. King-Song Jeng, and Dr. Nan-Haw for their contributions to common reference RNA mixtures, and Dr. FÄtima Al-Shahrour for allowing them to use the FatiGO algorithm. A special thank goes to Dr. Andrew Su (Genomics Institute of Novartis Research Foundation), Dr. Su-Fang Lin (National Health Research Institutes), Dr. Hung-Wen Chiu (Taipei Medical University), and Yang C. Fann (National Institute of Neurological Disorders and Stroke, National Institutes of Health) for the critical reading and inspiring comments on the manuscript. This research was supported, in part, by grants from the National Science Council (NSC93-3112-B-002-038 and NSC93-2320-B-002-112), the National Health Research Institutes (NHRI-EX92-9014BL), and the National Taiwan University Hospital (NTUH-92-S057, 93-S080, and 93A10-2) to C.-T. Lin; National Health Research Institutes and National Science Council (NRPGM: NSC93-3112-B-400-001) to C.-F. Huang; and National Science Council (NSC93-2320-B-038-043) and Topnotch Stroke Research Center Grant (Ministry of Education) to Y.-C. G. Lee. Yuan-Chii Gladys Lee and Yu-Chyi Hwang contributed equally to this work.

\section{References}

Al-Shahrour F, Diaz-Uriarte R, Dopazo J (2004) FatiGO: a web tool for finding significant associations of gene ontology terms with groups of genes. Bioinformatics 20:578-580

Armstrong RW, Armstrong MJ, Yu MC, Henderson BE (1983) Salted fish and inhalants as risk factors for nasopharyngeal carcinoma in Malaysian Chinese. Cancer Res 43:2967-2970

Brooks L, Yao QY, Rickinson AB, Young LS (1992) Epstein-Barr virus latent gene transcription in nasopharyngeal carcinoma cells: coexpression of EBNA1, LMP1, and LMP2 transcripts. J Virol 66:2689-2697

Busson P, Ganem G, Flores P, Mugneret F, Clausse B, Caillou B, Braham K, Wakasugi H, Lipinski M, Tursz T (1988) Establishment and characterization of three transplantable EBV-containing nasopharyngeal carcinomas. Int J Cancer 42:599-606
Chang Y, Sheen TS, Lu J, Huang YT, Chen JY, Yang CS, Tsai CH (1998) Detection of transcripts initiated from two viral promoters $(\mathrm{Cp}$ and $\mathrm{Wp}$ ) in Epstein-Barr virus-infected nasopharyngeal carcinoma cells and biopsies. Lab Invest 78:715-726

Cochet C, Martel-Renoir D, Grunewald V, Bosq J, Cochet G, Schwaab G, Bernaudin JF, Joab I (1993) Expression of the Epstein-Barr virus immediate early gene, BZLF1, in nasopharyngeal carcinoma tumor cells. Virology 197:358-365

Depper JM, Bluestein HG, Zvaifler NJ (1981) Impaired regulation of Epstein-Barr virus-induced lymphocyte proliferation in rheumatoid arthritis is due to a T cell defect. J Immunol 127:1899-1902

Epstein MA (1978) Epstein-Barr virus-discovery, properties and relationship to nasopharyngeal carcinoma. IARC Sci Publ :333-345

Fahraeus R, Fu HL, Ernberg I, Finke J, Rowe M, Klein G, Falk K, Nilsson E, Yadav M, Busson P et al (1988) Expression of Epstein-Barr virus-encoded proteins in nasopharyngeal carcinoma. Int J Cancer 42:329-338

Feng P, Chan SH, Ooi EE, Soo MY, Loh KS, Wang D, Ren EC, Hu H (1999) Elevated blood levels of soluble tumor necrosis factor receptors in nasopharyngeal carcinoma: correlation with humoral immune response to lytic replication of Epstein-Barr virus. Int J Oncol 15:167-172

Gilligan KJ, Rajadurai P, Lin JC, Busson P, Abdel-Hamid M, Prasad U, Tursz T, Raab-Traub N (1991) Expression of the Epstein-Barr virus BamHI A fragment in nasopharyngeal carcinoma: evidence for a viral protein expressed in vivo. J Virol 65:6252-6259

Gunven P, Klein G, Henle G, Henle W, Clifford P (1970) EpsteinBarr virus in Burkitt's lymphoma and nasopharyngeal carcinoma. Antibodies to EBV associated membrane and viral capsid antigens in Burkitt lymphoma patients. Nature 228:1053-1056

Henle W, Henle G (1970) Evidence for a relation of Epstein-Barr virus to Burkitt's lymphoma and nasopharyngeal carcinoma. Bibl Haematol (36): 706-713

Hitt MM, Allday MJ, Hara T, Karran L, Jones MD, Busson P, Tursz T, Ernberg I, Griffin BE (1989) EBV gene expression in an NPCrelated tumour. EMBO J 8:2639-2651

Ho CK, Lo WC, Huang PH, Wu MT, Christiani DC, Lin CT (1999) Suspected nasopharyngeal carcinoma in three workers with longterm exposure to sulphuric acid vapour. Occup Environ Med 56:426-428

Hsiao JR, Jin YT, Tsai ST (2002) Detection of cell free Epstein-Barr virus DNA in sera from patients with nasopharyngeal carcinoma. Cancer 94:723-729

Imai S, Nishikawa J, Takada K (1998) Cell-to-cell contact as an efficient mode of Epstein-Barr virus infection of diverse human epithelial cells. J Virol 72:4371-4378

Jones JF, Ray CG, Minnich LL, Hicks MJ, Kibler R, Lucas DO (1985) Evidence for active Epstein-Barr virus infection in patients with persistent, unexplained illnesses: elevated anti-early antigen antibodies. Ann Intern Med 102:1-7

Kikuta H, Taguchi Y, Tomizawa K, Kojima K, Kawamura N, Ishizaka A, Sakiyama Y, Matsumoto S, Imai S, Kinoshita T et al (1988) Epstein-Barr virus genome-positive $\mathrm{T}$ lymphocytes in a boy with chronic active EBV infection associated with Kawasaki-like disease. Nature 333:455-457

Klein G, Giovanella BC, Lindahl T, Fialkow PJ, Singh S, Stehlin JS (1974) Direct evidence for the presence of Epstein-Barr virus DNA and nuclear antigen in malignant epithelial cells from patients with poorly differentiated carcinoma of the nasopharynx. Proc Natl Acad Sci U S A 71:4737-4741

Leung SY, Chung LP, Yuen ST, Ho CM, Wong MP, Chan SY (1995) Lymphoepithelial carcinoma of the salivary gland: in situ detection of Epstein-Barr virus. J Clin Pathol 48:1022-1027

Leyvraz S, Henle W, Chahinian AP, Perlmann C, Klein G, Gordon RE, Rosenblum M, Holland JF (1985) Association of EpsteinBarr virus with thymic carcinoma. N Engl J Med 312:1296-1299 
Lin CT, Wong CI, Chan WY, Tzung KW, Ho JK, Hsu MM, Chuang SM (1990) Establishment and characterization of two nasopharyngeal carcinoma cell lines. Lab Invest 62:713-724

Lin CT, Chan WY, Chen W, Huang HM, Wu HC, Hsu MM, Chuang SM, Wang CC (1993) Characterization of seven newly established nasopharyngeal carcinoma cell lines. Lab Invest 68:716-727

Lin CT, Dee AN, Chen W, Chan WY (1994) Association of Epstein-Barr virus, human papilloma virus, and cytomegalovirus with nine nasopharyngeal carcinoma cell lines. Lab Invest 71:731-736

Lin CT, Lin CR, Tan GK, Chen W, Dee AN, Chan WY (1997) The mechanism of Epstein-Barr virus infection in nasopharyngeal carcinoma cells. Am J Pathol 150:1745-1756

Lin CT, Kao HJ, Lin JL, Chan WY, Wu HC, Liang ST (2000) Response of nasopharyngeal carcinoma cells to Epstein-Barr virus infection in vitro. Lab Invest 80:1149-1160

Lin JC, Chen KY, Wang WY, Jan JS, Liang WM, Tsai CS, Wei YH (2001) Detection of Epstein-Barr virus DNA the peripheral-blood cells of patients with nasopharyngeal carcinoma: relationship to distant metastasis and survival. J Clin Oncol 19:2607-2615

Lo YM, Chan LY, Chan AT, Leung SF, Lo KW, Zhang J, Lee JC, Hjelm NM, Johnson PJ, Huang DP (1999) Quantitative and temporal correlation between circulating cell-free Epstein-Barr virus DNA and tumor recurrence in nasopharyngeal carcinoma. Cancer Res 59:5452-5455

Lo YM, Chan WY, Ng EK, Chan LY, Lai PB, Tam JS, Chung SC (2001) Circulating Epstein-Barr virus DNA in the serum of patients with gastric carcinoma. Clin Cancer Res 7:18561859

Lo KW, To KF, Huang DP (2004) Focus on nasopharyngeal carcinoma. Cancer Cell 5:423-428

Luka J, Deeb ZE, Hartmann DP, Jenson B, Pearson GR (1988) Detection of antigens associated with Epstein-Barr virus replication in extracts from biopsy specimens of nasopharyngeal carcinomas. J Natl Cancer Inst 80:1164-1167

Miyasaka N, Yamaoka K, Tateishi M, Nishioka K, Yamamoto K (1989) Possible involvement of Epstein-Barr virus (EBV) in polyclonal B-cell activation in Sjogren's syndrome. J Autoimmun 2:427-432

Mueller N, Evans A, Harris NL, Comstock GW, Jellum E, Magnus K, Orentreich N, Polk BF, Vogelman J (1989) Hodgkin's disease and Epstein-Barr virus. Altered antibody pattern before diagnosis. N Engl J Med 320:689-695

Niedobitek G, Hansmann ML, Herbst H, Young LS, Dienemann D, Hartmann CA, Finn T, Pitteroff S, Welt A, Anagnostopoulos I et al (1991) Epstein-Barr virus and carcinomas: undifferentiated carcinomas but not squamous cell carcinomas of the nasopharynx are regularly associated with the virus. J Pathol $165: 17-24$

Nishikawa J, Imai S, Oda T, Kojima T, Okita K, Takada K (1999) Epstein-Barr virus promotes epithelial cell growth in the absence of EBNA2 and LMP1 expression J Virol 73:1286-1292

Novoradovskaya N, Whitfield ML, Basehore LS, Novoradovsky A, Pesich R, Usary J, Karaca M, Wong WK, Aprelikova O, Fero M, Perou CM, Botstein D, Braman J (2004) Universal reference RNA as a standard for microarray experiments. BMC Genomics $5: 20$
Ohigashi H, Koshimizu K, Tokuda H, Hiramatsu S, Jato J, Ito Y (1985) Epstein-Barr virus-inducing activity of Euphorbiaceae plants commonly grown in Cameroon. Cancer Lett 28:135- 141

Raab-Traub N, Hood R, Yang CS, Henry B 2nd, Pagano JS (1983) Epstein-Barr virus transcription in nasopharyngeal carcinoma. J Virol 48:580-590

Ross DT, Scherf U, Eisen MB, Perou CM, Rees C, Spellman P, Iyer V, Jeffrey SS, Van de Rijn M, Waltham M, Pergamenschikov A, Lee JC, Lashkari D, Shalon D, Myers TG, Weinstein JN, Botstein D, Brown PO (2000) Systematic variation in gene expression patterns in human cancer cell lines. Nat Genet 24:227-235

Sbih-Lammali F, Berger F, Busson P, Ooka T (1996a) Expression of the DNase encoded by the BGLF5 gene of Epstein-Barr virus in nasopharyngeal carcinoma epithelial cells. Virology 222:64-74

Sbih-Lammali F, Djennaoui D, Belaoui H, Bouguermouh A, Decaussin G, Ooka T (1996b) Transcriptional expression of Epstein-Barr virus genes and proto-oncogenes in North African nasopharyngeal carcinoma. J Med Virol 49:7-14

Sixbey JW, Yao QY (1992) Immunoglobulin A-induced shift of Epstein-Barr virus tissue tropism. Science 255:1578-1580

Straus SE, Dale JK, Wright R, Metcalfe DD (1988) Allergy and the chronic fatigue syndrome. J Allergy Clin Immunol 81:791- 795

Teng ZP, Ooka T, Huang DP, Zeng Y (1996) Detection of EpsteinBarr Virus DNA in well and poorly differentiated nasopharyngeal carcinoma cell lines. Virus Genes 13:53-60

Teramoto N, Maeda A, Kobayashi K, Hayashi K, Oka T, Takahashi K, Takada K, Klein G, Akagi T (2000) Epstein-Barr virus infection to Epstein-Barr virus-negative nasopharyngeal carcinoma cell line TW03 enhances its tumorigenicity. Lab Invest 80:303-312

Tsai ST, Jin YT, Su IJ (1996) Expression of EBER1 in primary and metastatic nasopharyngeal carcinoma tissues using in situ hybridization. A correlation with WHO histologic subtypes. Cancer 77:231-236

Vasef MA, Ferlito A, Weiss LM (1997) Nasopharyngeal carcinoma, with emphasis on its relationship to Epstein-Barr virus. Ann Otol Rhinol Laryngol 106:348-356

Waterhouse L, Muir C, Shanmugaratnam K, Powell J, Peachham D, Whelan S (1982) Cancer incidence in five continents. International Agency for Research on Cancer, Lyon

Winrow VR, Norton J, Holborow EJ, Stierle HE, Young A, Sachs JA (1988) T cell cytotoxicity to Epstein-Barr virus infected B cells: comparison of patients with rheumatoid arthritis and their HLA identical siblings. Ann Rheum Dis 47:280-285

Wu HC, Lin YJ, Lee JJ, Liu YJ, Liang ST, Peng Y, Chiu YW, Wu CW, Lin CT (2003) Functional analysis of EBV in nasopharyngeal carcinoma cells. Lab Invest 83:797-812

Wu HC, Lu TY, Lee JJ, Hwang JK, Lin YJ, Wang CK, Lin CT (2004) MDM2 expression in EBV-infected nasopharyngeal carcinoma cells. Lab Invest 84:1547-1556

Young LS, Dawson CW, Clark D, Rupani H, Busson P, Tursz T, Johnson A, Rickinson AB (1988) Epstein-Barr virus gene expression in nasopharyngeal carcinoma. J Gen Virol 69(Pt 5):1051-1065

zur Hausen H, Schulte-Holthausen H, Klein G, Henle W, Henle G, Clifford P, Santesson L (1970) EBV DNA in biopsies of Burkitt tumours and anaplastic carcinomas of the nasopharynx. Nature 228:1056-1058 